\title{
EXPERIMENTAL INVESTIGATIONS OF SURFACE WEAR BY DRY SLIDING AND INDUCED DAMAGE OF MEDIUM CARBON STEEL
}

\author{
Abdelmalek ELHADI ${ }^{1,2}$, Salah AMROUNE ${ }^{1,2}$, Moussa ZAOUI ${ }^{1,2}$, Barhm MOHAMAD ${ }^{3}$, \\ Ali BOUCHOUCHA ${ }^{4}$ \\ ${ }^{1}$ University of Mohamed Boudiaf, Msila; B.P 166 ICHBELIA. Msila 28000 Algeria. \\ ${ }^{2}$ Laboratoire de Matériaux et Mécanique des Structures (LMMS), Université de M'sila. Algérie \\ ${ }^{3}$ Faculty of Mechanical Engineering and Informatics-University of Miskolc, 3515 Miskolc-Hungary. \\ ${ }^{4}$ Tribology laboratory, Department of Mechanical Engineering, Faculty of Science and Technology, Mentouri \\ Brothers University, Constantine1, Algeria.
}

E-mail: abdelmalek.elhadi@univ-msila.dz, salah.amroune@univ-msila.dz, moussa.zaoui@univ-msila.dz, pywand@gmail.com, bouchoucha_ali1@yahoo.fr

Abstract

This study concerns the wear behaviour of metal couples used in industry, particularly in mechanical sliding systems (numerically controlled machine tools). In general, the nature of the materials of the parts of these systems which are in contact and move relatively, are medium carbon steels, thanks to their good mechanical and tribological properties. The present work aims to study, the dry sliding wear of the contact surface of the pin (machine slide) against the contact surface of a disc (machine groove) and the damage induced on the worn track. The pin is AISI 1038 and AISI 1045 steel, the disc is AISI 1055 steel. The tribological tests were carried out on a pin-disc tribometer, in an atmospheric environment. The wear of the pins being evaluated by weighing and studied according to the hardness of the pin with the variation of the normal load applied. The discussion of the results is based on SEM observations and EDS analyzes of worn surfaces and interfacial phenomena produced by dynamic contact. The results obtained indicated the influence of the applied load and the hardness on the wear of the pin and therefore on the tribological behaviour of the worn surfaces.

Keywords: Hardness, friction, microstructure of steels, heat treatment, wear.

\section{INTRODUCTION}

In industry, there are a very large number of applications whose mechanisms are often subject to friction and wear.

The resulting wear of the rubbing surfaces is reflected, most often during operation, by geometric modifications, physicochemical transformations, by material removal or even by a rise in temperature. In its aspects, wear is a complex phenomenon whose study requires multiple approaches $[1,2]$.

The presence of wear in the parts can be the origin of a reduction in the efficiency of the mechanical system or even be the cause of the invalidity of this system [3, 4]. The precision of machine tools is continuously degraded throughout their life cycle. Diagnosis of this anomaly reveals the wear of their structural components such as bearings, ball screws and guides. The main criteria for selecting steels for parts subject to wear are usually based on the hardness of the surface [5]. Research has investigated the effect of hardness on the wear rate $[6,7]$.
The rate of wear may also be related to other factors such as microstructure and its characteristics $[8,9]$.

Studies show that chemical compositions, alloying elements and microstructures of materials have an impact on the wear behavior of materials [10-15].

The mechanical characteristics, hardness and toughness of steels depend on microstructural characteristics such as the size of the old austenitic grain $[16,17]$ the interlamellar spacing [18-20], the volume fraction of cementite and its morphology [21].Improving mechanical properties, such as hardness increases the wear resistance of materials and plays a primary and important role in the longevity of mechanical parts of machines (CNC) and reducing energy loss [22].Quenching and tempering make it possible to modify and improve the mechanical properties of steel: elastic limit, tensile strength, toughness, hardness and resilience.

The objective of this work is to study the influence of the applied normal load and hardness on the wear of the pin and the consequences on the rubbing surfaces. 


\section{MATERIALS AND METHODOLOGY}

\subsection{Used materials}

The pin is AISI 1038 steel with a hardness of $185 \mathrm{HV}$ and AISI 1045 steel with a hardness of $210 \mathrm{HV}$ (as delivered). It is a rod of $4 \mathrm{~mm}$ diameter and $20 \mathrm{~mm}$ length, tapered end with a flat contact surface of $2 \mathrm{~mm}$ in diameter. The disc is made of AISI 1055 treated steel with 52HRC hardness (martensitic structure). It is a circular plate $50 \mathrm{~mm}$ in diameter and $10 \mathrm{~mm}$ thick. The chemical composition of the materials is shown in Table 1.

Table 1. Chemical composition of materials

\begin{tabular}{|c|c|c|c|c|c|}
\hline Steel & Elem & $\mathbf{C}$ & $\mathbf{S i}$ & $\mathbf{M n}$ & $\mathbf{P}$ \\
\hline AISI 1038 & $\%$ & 0,37 & 0,35 & 0,60 & 0,045 \\
\hline AISI 1045 & $\%$ & 0,49 & 0,30 & 0,71 & 0,035 \\
\hline AISI 1055 & $\%$ & 0,54 & 0,41 & 0,74 & 0,03 \\
\hline Steel & Elem & $\mathbf{C r}$ & $\mathbf{M o}$ & $\mathbf{N i}$ & $\mathbf{S}$ \\
\hline AISI 1038 & $\%$ & 0,10 & 0,01 & 0,03 & 0,02 \\
\hline AISI 1045 & $\%$ & 0,14 & 0,02 & 0,14 & 0,025 \\
\hline AISI 1055 & $\%$ & 0,15 & 0,02 & 0,06 & 0,03 \\
\hline
\end{tabular}

\subsection{Methodology}

The couples of steels used are AISI 1038 and AISI 1045 untreated and treated with AISI 1055 treated. The selection of materials was based on the wide application of these steels in different parts of mechanical systems.

After heat treatment (quenching and tempering), the hardness of AISI 1038 steel is 30HRC and 35HRC for AISI 1045 steel. The average roughness of the contact surfaces of the pins and discs is $\mathrm{Ra}=$ $0.06 \mu \mathrm{m}$. Each test lasted 3600s, the normal load varied between $5 \mathrm{~N}$ and $40 \mathrm{~N}$. The linear sliding speed is constant at $0.5 \mathrm{~m} / \mathrm{s}$. Wear tests were repeated three times to get an average value.

The dry sliding wear tests were carried out in air at room temperature, of about $25 \pm 2{ }^{\circ} \mathrm{C}$, using a tribometer (pin on disc system) type TE91 as shown in figure 1. It is based on the principle of the wear machine by sliding. The pin is secured in a hole with a locking screw on an aluminium load arm. It is loaded against a disc by masses of varying weight. The disc is fixed on a support and rotates at varying rotational speeds.

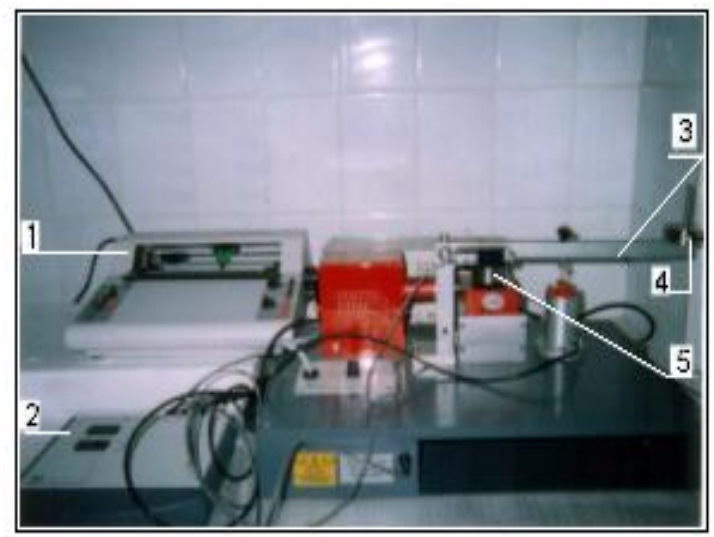

Fig. 1. Tribometer type TE91: 1 - recorder; 2 display box; 3 - load lever; 4 - applied load; 5 - disc
Figure 2 shows the contact between the pin and the disc and the resulting wear track.

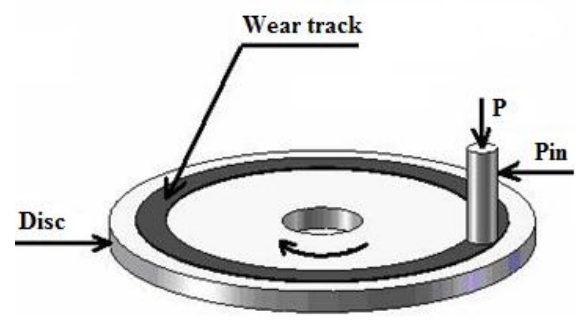

Fig. 2. Pin-disc contact

The spent mass of pin sample was measured by an electronic balance with an accuracy of $10^{-4} \mathrm{~g}$. The micrographic images were taken using a metallographic microscope of the type: OLYMPUS PME3, equipped with a photo-taking system, which allows the observation of samples, with a magnification of up to 900 times. We took micrographs of the samples before and after the heat treatments performed. The images of the worn surfaces were analysed with a scanning electron microscope of the type: JEOL JSM-6390 LV.

\section{RESULTS AND DISCUSSION}

Figure 3 shows that the variation in pin wear is a linear function with the normal load $\mathrm{P}$ applied.

The untreated AISI 1038 pin generally shows a high mass loss compared to the untreated AISI 1045 pin (fig. 3a).

The AISI 1038 and AISI 1045 treated pins indicate a lower mass loss than the untreated pins (Fig. $3 \mathrm{~b}$ and $3 \mathrm{c}$ ).

The four pins (AISI 1038 and AISI 1045 untreated and treated), reveals that the treated AISI 1045 pin shows the smallest loss in mass.

The structure of the untreated pins is feritoperlitic (hypo-eutectoid) cellular (fig. 4a and $4 \mathrm{~b})$ characterized by low hardness $(220 \mathrm{HV}$ for perlite and $80 \mathrm{HV}$ for ferrite).

The structure of the untreated pins is feritoperlitic (hypo-eutectoid) cellular (fig. 4a and $4 b)$ characterized by low hardness $(220 \mathrm{HV}$ for perlite and $80 \mathrm{HV}$ for ferrite).

Image analysis using the $\mathrm{J}$ image software in figure $4 \mathrm{a}$ and $4 \mathrm{~b}$, gives us the figure $4 \mathrm{c}$ and $4 \mathrm{~d}$ images and the proportion of ferrite and pearlite. The loss in mass of untreated AISI 1038 pins is greater than that of untreated AISI 1045 pins, because the area proportion ferrite of AISI 1038 $(34.17 \%)$ is greater than that of AISI $1045(24.5 \%)$ and the area proportion pearlite of AISI 1045 $(75.5 \%)$ is higher than that of AISI 1038 steel $(65.82 \%)$, and it is well known that pearlite is harder than ferrite. This means that AISI 1045 is harder than AISI 1038 steel. 

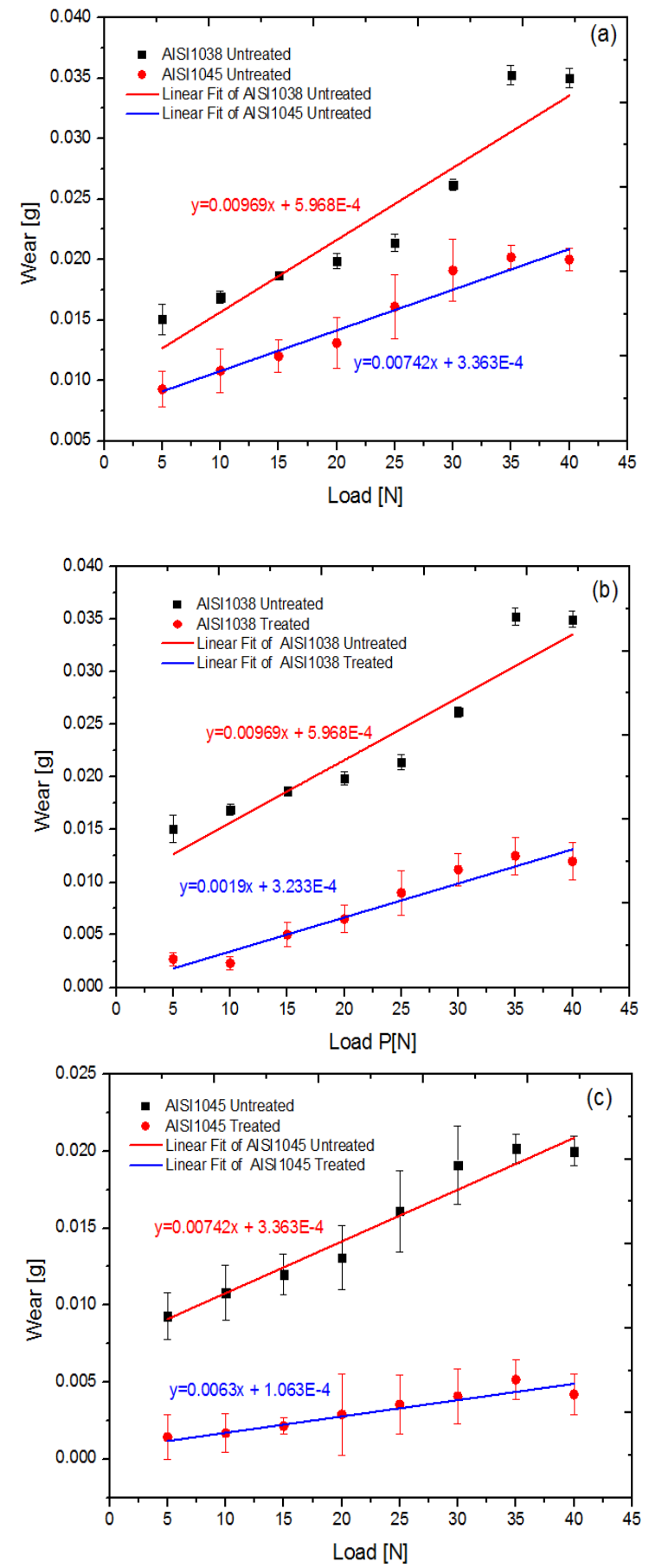

Fig. 3. Variation of wear of untreated and treated pins as a function of the normal load $\mathrm{P}$

The increase in the percentage of addition elements such as $\mathrm{Mn}$ and $\mathrm{Cr}$ also justifies the increase in the hardness of AISI 1045 steel compared to AISI 1038 steel.

For small loads $(5 \mathrm{~N}$ to $20 \mathrm{~N})$, the wear rate of the pins is low because of the limited number of contact points between the surfaces, as well as the important role that the adsorbed layer plays as a lubricating element [23]. The increase in charge results in an increase in the actual contact area and then in an increase in the density of the junctions and in the temperature at the interface, which facilitates the formation of the oxide. The oxide

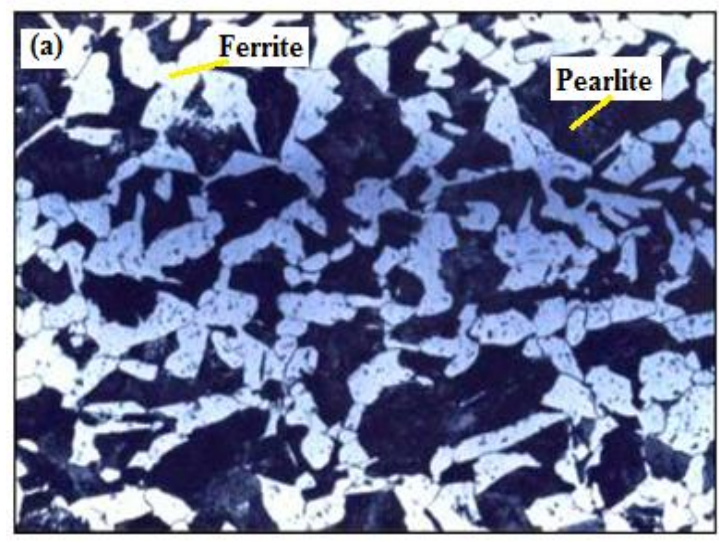

Magnification $(\times 200)$

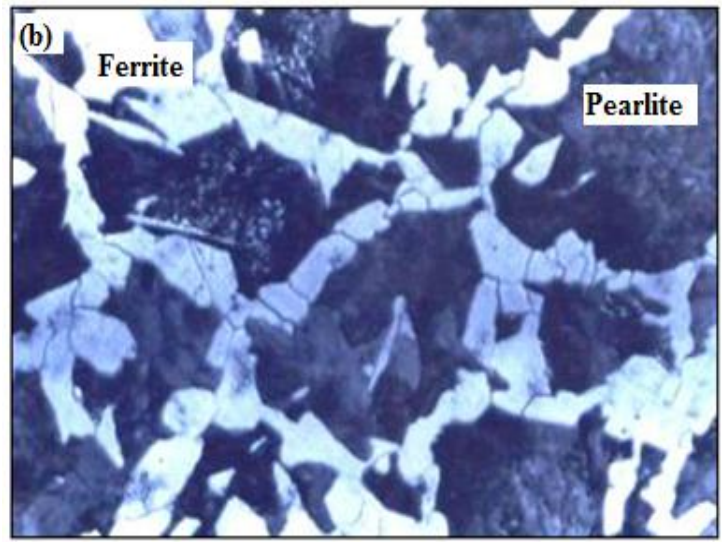

Magnification $(\times 200)$
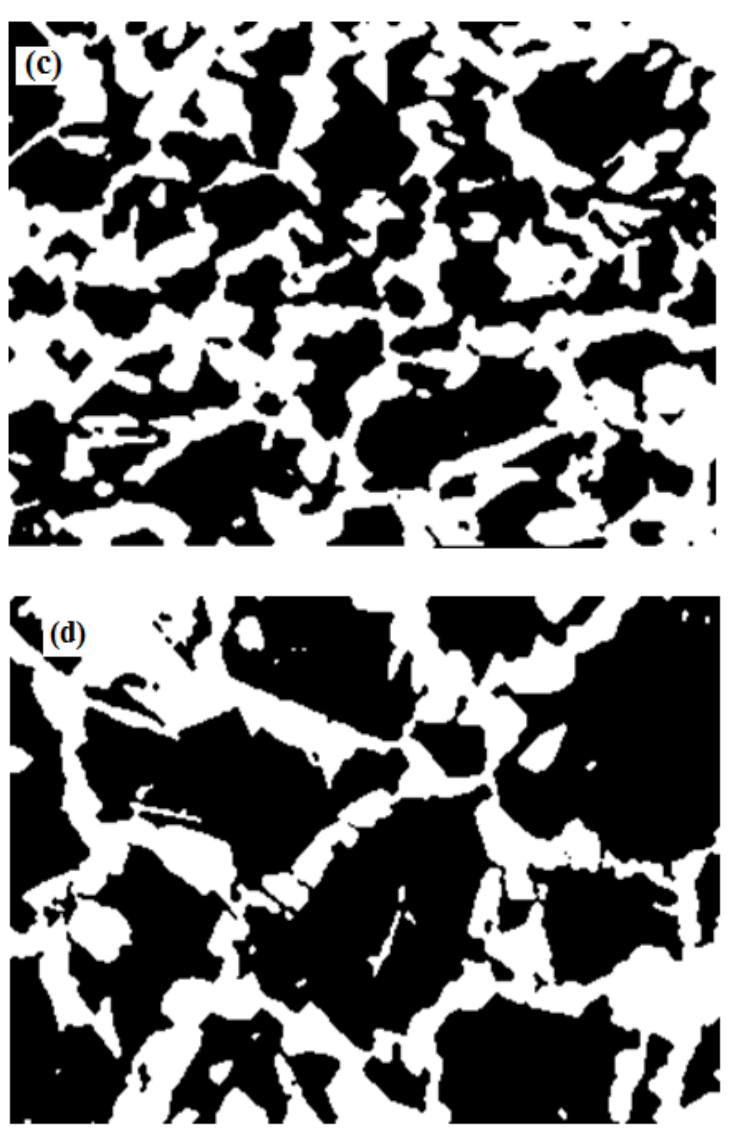

Fig. 4. Micrography of untreated steels:

(a) and (c) : AISI 1038; (b) and (d): AISI 1045 
produced and the contact pressures reached are then high enough to cause their plastic deformation rather than their rupture and consequently to the growth of wear [24].

SEM observations of the wear patterns of the pins make it possible to identify the degradations which vary according to the load.

For the untreated pin, at the applied load 20N, the worn track (fig. 5) exhibits areas of friction giving the impression of plastic deformation and plowing of rubbed surfaces with a small adhesion (fig. 5a).

The grooves are plowed parallel to the direction of movement of the asperities (fig. 5b), particles distributed along the wear track. Wear is produced by the hard asperities of the contact surface of the disc on the contact surface of the pin (abrasive wear with two bodies).
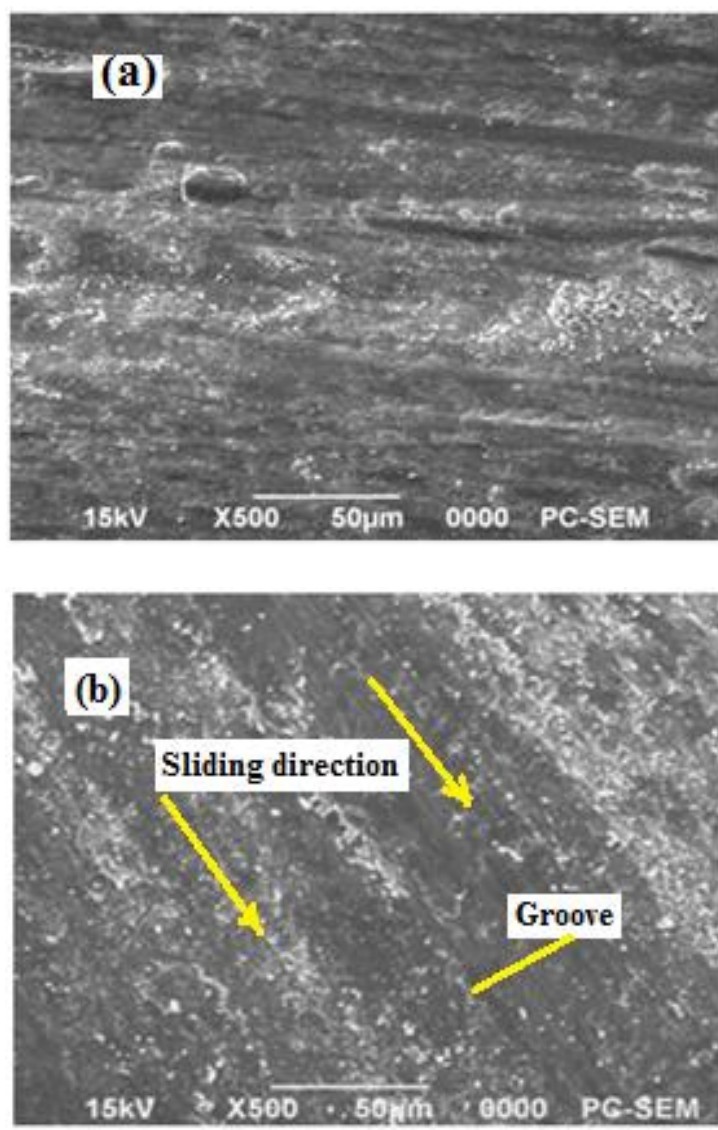

Fig. 5. Worn pin surfaces: (a) AISI 1038 untreated; (b) AISI 1045 untreated $(\mathrm{P}=20 \mathrm{~N})$

At high load, adhesion, delamination and oxidation mechanisms have been observed. Significant damage is noticed on the worn surface (fig. 6.b). The main characteristics of the damage are delamination and severe plastic deformation and chipping of debris. This debris oxidizes, becomes hard and abrasive, and forms the third body. A protective oxide layer covers the majority of the contact surface of the pins and reduces the rate of wear.
The oxidative mechanism is confirmed by the associated EDS spectra (fig. 6c and 6d).
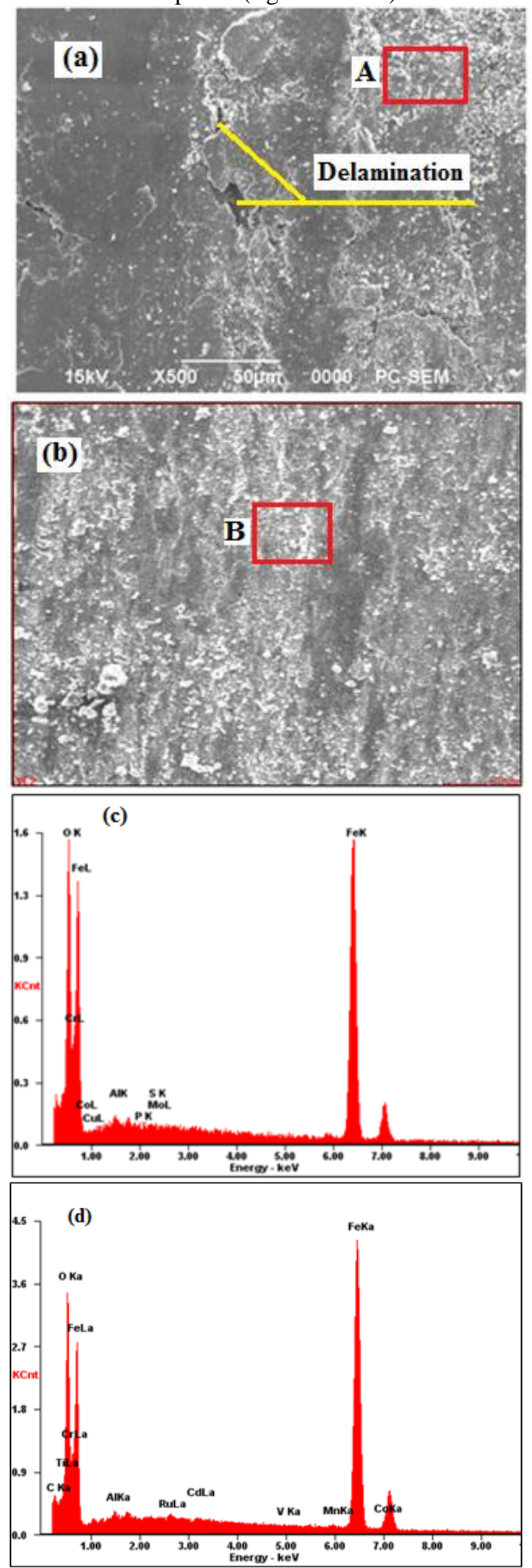

Fig. 6. Worn surfaces of untreated pins:

(a) AISI 1038; (b) AISI 1045; (c) EDS spectrum of zone $\mathrm{A}$ in fig. $6 \mathrm{a}$; (d) EDS spectrum associated with zone $B$ in fig. $6 \mathrm{~b}, \mathrm{P}=40 \mathrm{~N}$ 
The martensitic structure of the pins obtained after austenization at $850{ }^{\circ} \mathrm{C}$ for AISI 1038 and at $830{ }^{\circ} \mathrm{C}$ for AISI 1045 for 30 minutes for the homogenization of the structure and quenching in water at $25{ }^{\circ} \mathrm{C}$ as a cooling medium for the formation of martensite.

Figure 7 is the microstructure of AISI 1045 steel after quenching, it is an elongated phase in flattened shape (needles or slats), characterized by great hardness and brittleness with distortions deformations produced during martensitic transformation. It is then necessary to follow the quenching by a tempering.

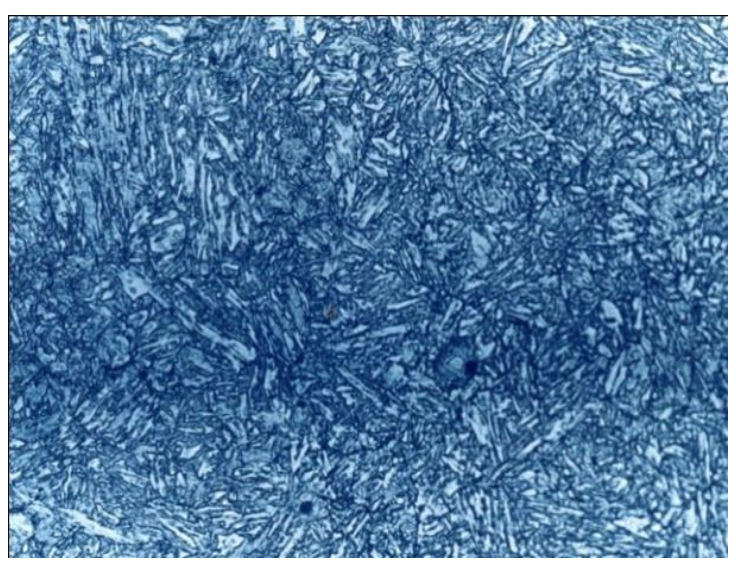

Fig. 7. Microstructure of AISI 1045 steel after quenching at $830{ }^{\circ} \mathrm{C}(\mathrm{x} 500)$

After the application of tempering on AISI 1038 and AISI 1045 steels at $500{ }^{\circ} \mathrm{C}$, the microstructure will return to its stable state, that is to say (ferrite $\alpha$ $+\mathrm{Fe}_{3} \mathrm{C}$ ) which influences the hardness of the steel. It is clear that the microscopic observations show the presence of a high proportion of lamellar perlite characterized by long lamellae (fig. 8a). Figure 8b shows the microstructure of AISI 1045 steel after quenching and tempering at $500{ }^{\circ} \mathrm{C}$. We can give the same previous interpretation except that the perlite lamellas are very diverse in their orientations and shorter than the lamellae of AISI 1038, this is why the hardness of AISI 1045 steel increases and resists wear better than AISI 1038 steel.

The SEM observations made it possible to identify the typical characteristics of damage in the worn surfaces according to the normal load and the hardness of the pins. For the pin of high hardness, at an applied load of $20 \mathrm{~N}$, the worn surface shows a smooth surface with signs of plowing and small plastic deformations (fig. 9a). In addition, resulting fine particles were observed on the generated micro-grooves. Tearing of the material (rupture of the junction) and shearing of the wear debris observed from the roughness of the disc surface on the pin surface (fig. 9b). As the hardness increases, the junctions formed become very small and the traces of adhesion decrease, we can distinguish a fineness of adhesion.
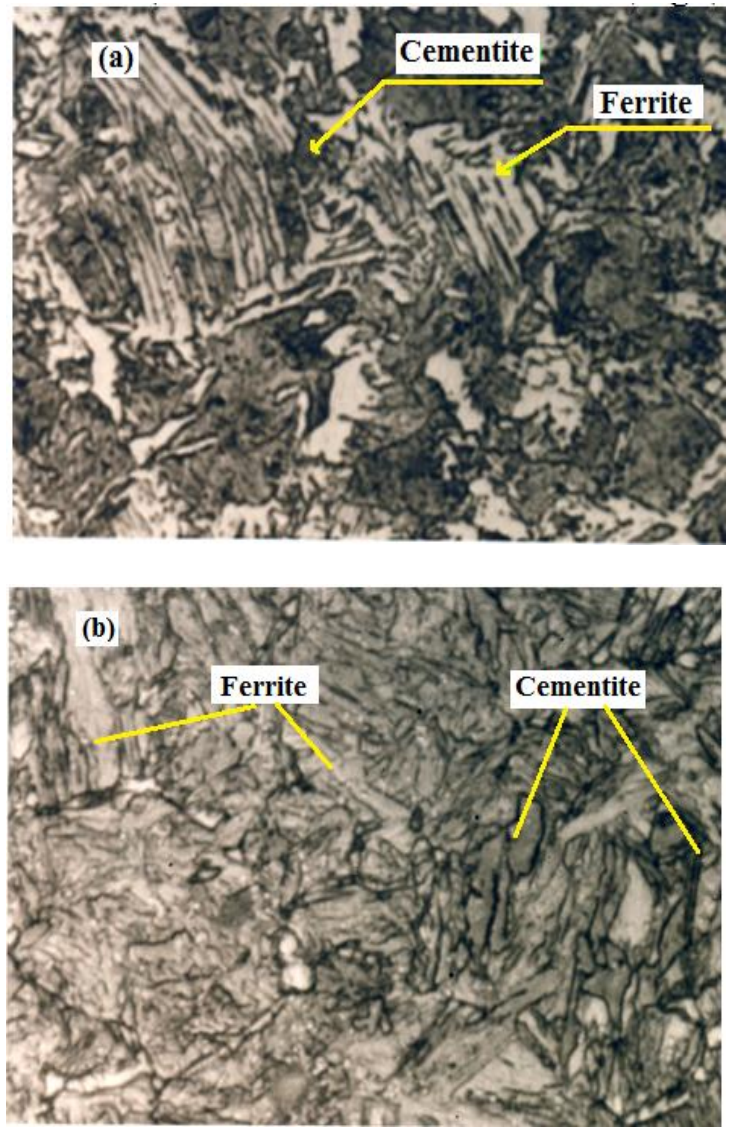

Fig. 8. Microstructure of steels after tempering: (a) AISI 1038 of hardness 30HRC; (b) AISI 1045 with hardness 35HRC (x900)
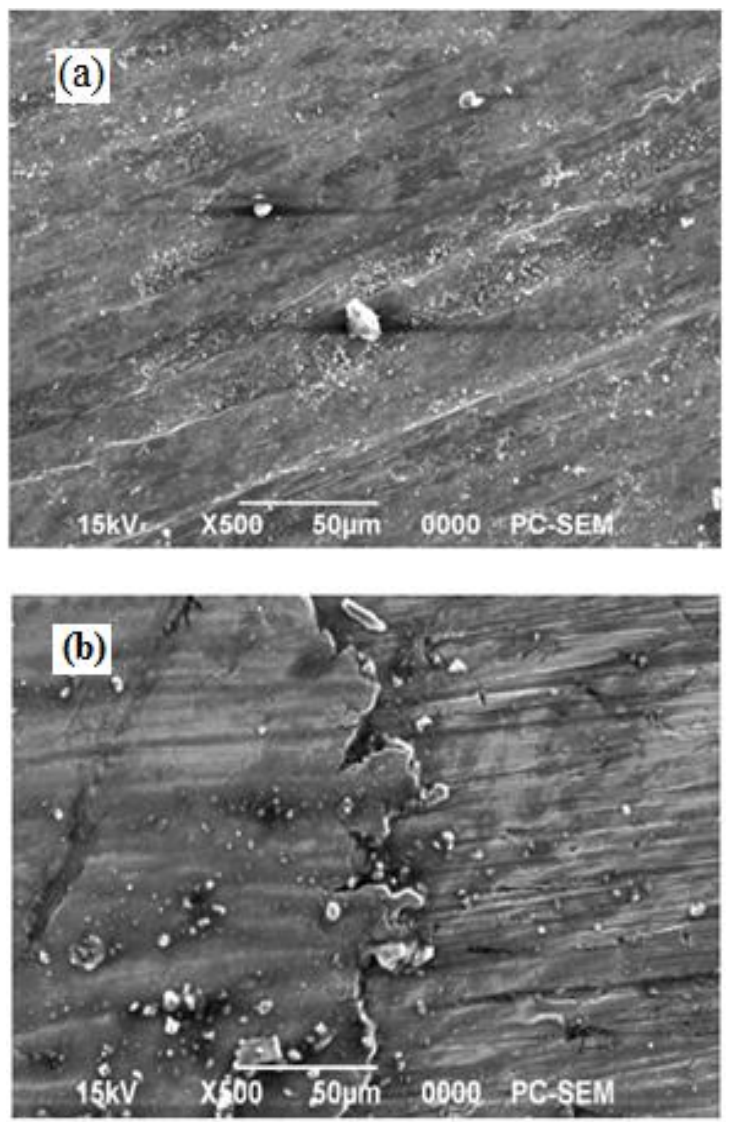

Fig. 9. Worn pin surfaces: (a) AISI 1038; (b) AISI $1045, \mathrm{P}=20 \mathrm{~N}$ 

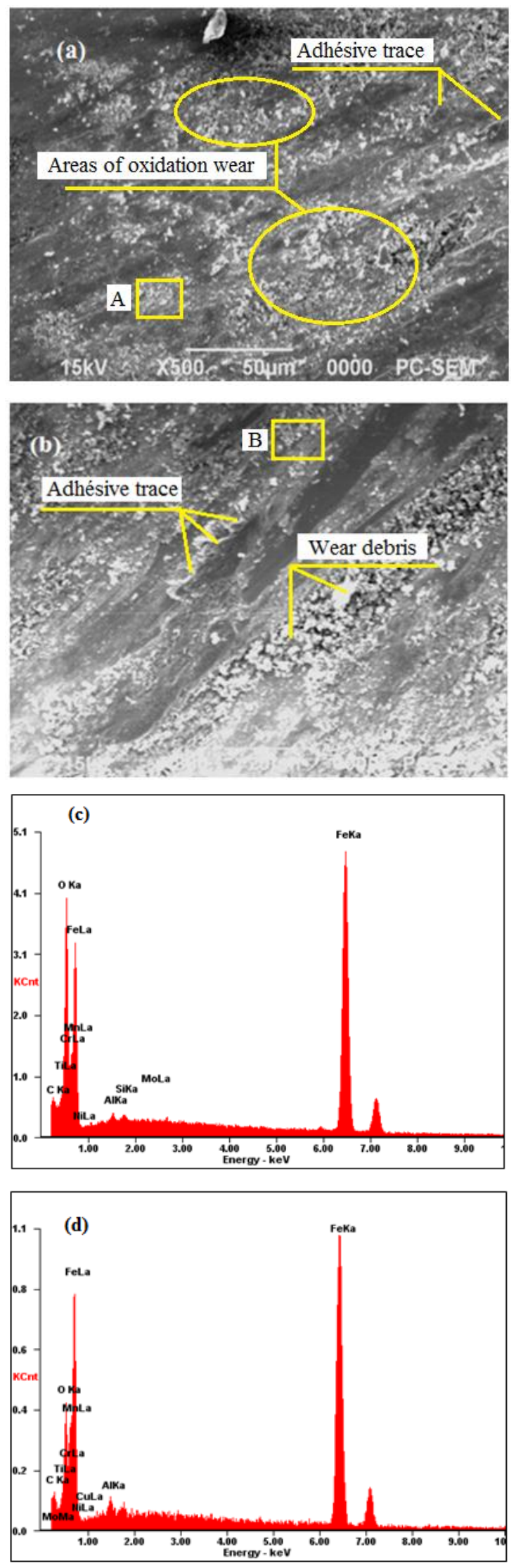

Fig. 10. Worn surfaces of treated pins: (a) AISI 1038; (b) AISI 1045; (c) EDS spectrum of zone A in fig. 10a; (d) EDS spectrum of zone B in fig. $10 \mathrm{~b}, \mathrm{~N}=40 \mathrm{~N}$
As the load increases to $40 \mathrm{~N}$, an oxide layer develops and covers the surface of the pin (fig. 10a and $10 \mathrm{~b}$ ), the type of wear developed is oxidative (oxidative wear) with adhesive traces. This oxide film plays a protective role and considerably reduces wear [25]. The grooves are interrupted and isolated (fig. 10b), implying the presence of hard particles produced between the surfaces during friction and causing abrasive wear to three bodies. In addition, we also note the existence of adhesive traces.

\section{CONCLUSION}

The work carried out in this article consists in studying the wear behaviour of two pairs of medium carbon steels with dry sliding contact.

The results obtained and the metallographic observations show that the wear of the pin is a function of its microstructure. The loss in mass is important if the pin is used in the delivered state (feritoperlitic cell structure) of which the hardness is low. The carbon content and the additives affect the hardness of the materials. The change in wear is a linear function with the applied normal load.

The application of quenching and tempering on the pegs improves mechanical properties, such as hardness which increases wear resistance. The formation of abrasive grains plows the surfaces and considerably increases the wear of the pin. The most wear-resistant and best-used steel for manufacturing mechanical parts that are in dynamic contact is AISI 1045 treated steel.

\section{ACKNOWLEDGEMENTS}

The authors are also grateful for the technical support of the Tribology Laboratory of the Department of Mechanical Engineering of the University of Constantine 1, Algeria.

They also thank Doctor Ghouss Haoues from the University of Badji Mokhtar Annaba, Algeria for his help.

\section{REFERENCES}

1. Madakson PB. The friction behaviour of materials. Wear. 1983; 87:191-206. https://doi.org/10.1016/0043-1648(83)90034-0

2. Godet M. The third-body approach. Wear. 1984; 100:437-452. https://doi.org/10.1016/0043648(84)90025-5

3. Jean-Marie George. Friction, wear and lubrication, Eyrolles. 2000.

4. Št'astniak P, Smetanka L, Drozdziel P. computer aided simulation analysis for wear investigation of railway wheel running surface, Diagnostyka. 2019; 20;3: 6368. https://doi.org/10.29354/diag/111569.

5. Bressana JD, Darosa DP, Sokolowskib A, Mesquitac RA, Barbosad CA. Influence of hardness on the wear resistance of 17-4 PH stainless steel evaluated by the pin-on-disc testing, Journal of materials processing 
technology. 2008;205:353-359.

https://doi.org/10.1016/j.jmatprotec.2007.11.251

6. Tang L, Gao C, Huang J, Huang J, Zhang H, Chang W. Dry sliding friction and wear behaviour of hardened AISI D2 tool steel with different hardness levels. Tribology International. 2013; 66:165-173. https://doi.org/10.1016/j.triboint.2013.05.006

7. Coronado JJ, Rodríguez SA, Sinatora A. Effect of particle hardness on mild-severe wear transition of hard second phase materials. Wear. 2013; 301:82-88. https://doi.org/10.1016/j.wear.2012.12.016

8. Abouei V, Saghafian $\mathrm{H}$, Kheirandish $\mathrm{S}$. Effect of microstructure on the oxidative wear behavior of plain carbon steel. Wear. 2007; 262. 9-10, 12251231. https://doi.org/10.1016/j.wear.2006.11.009

9. Ilaiyavel S, Venkatesan A. The Wear behaviour of Manganese Phosphate Coatings applied to AISI D2Steel Subject to Different Heat Treatment Processes. Procedia engineering. 2012; 38: 19161924. https://doi.org/10.1016/j.proeng.2012.06.234

10. Katsuki F, Watari K, Tahira H, Umino M. Abrasive wear behavior of a pearlitic $(0.4 \% \mathrm{C})$ steelmicroalloyed with vanadium. Wear. 2008; 264(3-4):331-336.

https://doi.org/10.1016/j.wear.2007.03.023

11. Máscia R, Ramos Neto FF, Barbosa Neto TF, Franco SD. Effects of pressure and counterbody hardness in the abrasive wear behavior of tool steels. Wear. 2031; 303(1-2):412-418. https://doi.org/10.1016/j.wear.2013.03.037

12. Ojala N, Valtonen K, Heino V, Kallio M, Aaltonen J, Siitonen P, Kuokkala VT. Effects of composition and microstructure on the abrasive wear performance of quenched wear resistant steels. Wear. 2014;317:(12):225-232.

https://doi.org/10.1016/j.wear.2014.06.003

13. Sondur DG, Kabadi VR, Mallapur DG. Influence of martensite phase on the tribological properties of plain carbon steel. Procedia Materials Science. 2014; 5: 464-471.

https://doi.org/10.1016/j.mspro.2014.07.289

14. Modi AP. Effects of microstructure and experimental parameters on high stress abrasive wear behaviour of a $0.19 \mathrm{wt} \% \mathrm{C}$ dual phase steel. Tribology International. 2007;40:490-497.

https://doi.org/10.1016/j.triboint.2006.04.013

15. Singh K, Khatirkar RK, Sapate SG. Microstructure evolution and abrasive wear behavior of D2 steel. Wear. 2015;206-216. https://doi.org/10.1016/j.wear.2015.02.019

16. Hyzak JM, Bernstein IM. The role of microstructure on the strength and toughness of fully pearlitic steels. Metallurgical Transactions. 1976; 7A:1217-1224. https://doi.org/10.1007/BF02656606

17._Marder AR, Bramfitt BL. .The effect of morphology on the strength of pearlite. Metallurgical Transactions A. 1976;7A:365-372. https://doi.org/10.1007/BF02642832

18. Dollar M, Berveiller M, Thompson AW. Influence of deformation substructure on flow and fracture of fully pearltic steel. 1988; Acta Materialia.36:311-320. https://doi.org/10.1016/0001-6160(88)90008-9

19. Elwazri AM, Wanjara P, Yuea S. The effect of microstructural characteristics of pearlite on the mechanical properties of hypereutectoid steel. Materials Science and Engineering. 2005;404:91-98. https://doi.org/10.1016/j.msea.2005.05.051
20. Modia OP, Deshmukhb N, Mondala DP, Jha AK. Yegneswarana AH, Khairac HK. Effect of interlamellar spacing on the mechanical properties of $0.65 \%$ C steel. Materials characterization. 2001; 46:347-352. https://doi.org/10.1016/S10445803(00)00113-3

21. Lei C, Gotoh M, Horimoto Y, Hirose Y. Effect of Microstructure of Cementite on Interphase Stress State in Carbon Steel. Journal of iron and steel research international. 2007;14:31-38. https://doi.org/10.1016/S1006-706X(07)60054-5

22. Trevisiol C, Jourani A, Bouvier S. Effect of hardness, microstructure, normal load and abrasive size on friction and on wear behaviour of 35NCD16 steel. Wear. 2017;388-389:101-111. https://doi.org/10.1016/j.wear.2017.05.008

23. Barrau O. Study of friction and wear of tool steels hot work, doctoral thesis. National Polytechnic Institute of Toulouse, France, 2004.

24. Ezugwu EO, Okeke CI, Machado AR. High speed threading of inclusion-modified steels with coated carbide tools. Journal of Materials Processing Technology. 1998;86(1-3):216-225. https://doi.org/10.1016/S0924-0136(98)00313-6

25. Bouchoucha A, Chekroud S, Paulmier D. The influence of oxygen on the friction and wear behaviour of a copper-steel couple under electric current. Tribotest. 2004;11(1):11-27. https://doi.org/10.1002/tt.3020110103.

\section{Received 2020-11-03}

Accepted 2021-03-08

Available online 2021-03-09

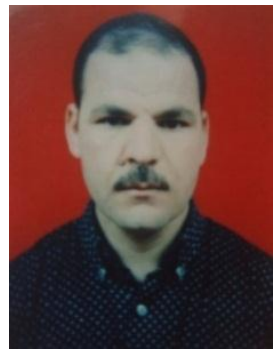

Abdelmalek ELHADI was born in M'sila, Algeria. He received from Mohamed Boudiaf University, Msila, Algeria his Mechanical state engineer diploma in 1990 and doctorate degree in mechanical engineering from the University of Constantine in 2018. His research interests are materials, from the point of view of: metallurgy, mechanical properties, tribological behavior and characterizations.

E-mail address: abdelmalek.elhadi@univ-msila.dz

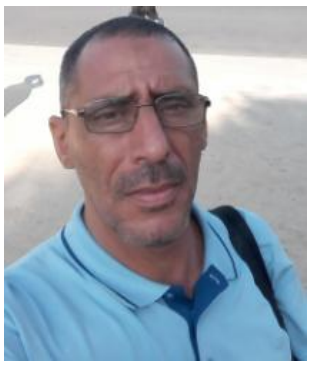

Salah AMROUNE was born in Msila, Algeria. He received from M'sila University of Algeria his Mechanical state engineer diploma in 1992 and doctorate degree in mechanical engineering from the 08 Mai 1945 Guelma. University of Algeria in 2016. His research activities are based on the characterization of natural fibers and bio composites, Plus, modelling and numerical simulation of $\mathrm{CNC}$ machining. E-mail address: salah.amroune@univmsila.dz

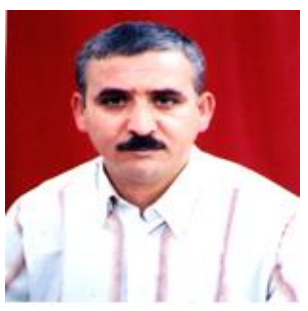

Moussa ZAOUI was born in M'sila, Algeria. He received from polytechnic University of Algeria his Mechanical state engineer diploma in 1985 and 
doctorate degree in mechanical engineering from the Constantine University of Algeria in 2009. His research activities are based on Characterization of the welding joint and welding technique.

E-mail : $\underline{\text { moussa.zaoui@univ-msila.dz }}$

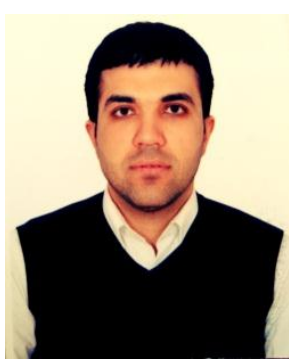

Barhm MOHAMAD received his M.E. degree in Mechanical Engineering in 2012 and start his Ph.D studies in 2016 in Faculty of Mechanical Engineering and Informatics University of Miskolc Hungary, respectively. Since 2018 He has been a technical researcher in the Formula Student-Miskolc at the University of Miskolc, His scientific interests focus on engine powertrain and diagnostics. He has participated in 5 international and 3 national research projects, presenting results of his work at 10 international and 4 national conferences, published more than 15 scientific papers in international and national journals, book chapters, as well as conference proceedings.

E-mail address: pywand@gmail.com 